\title{
Human Characters and Morality in Ibn Hazm's Philosophical Aphorisms
}

\author{
Tomasz Stefaniuk \\ (D) https://orcid.org/0000-0002-0009-3142
}

\begin{abstract}
The author analyzes the philosophical thoughts outlined by Ibn Hazm in his $A l-A \underline{h} l a \bar{q}$ wa-' 1 -Siyar treatise. Apart from friendship, love, social relationships, the complexity of human characters and the diversity of life attitudes, the one issue discussed in the treatise first and foremost is the meaning and significance of human life. The Arab philosopher refers to all these issues as a rationalist despite ultimately presenting a clearly religious-oriented position. His ethical views are rooted not only in a religious (Muslim) tradition, but also in that of classical philosophy, reflecting a particularly strong convergence with the ethics of the Stoics and Aristotle.
\end{abstract}

Keywords: philosophy, Arab philosophy, Islamic philosophy, ethics, moralistic literature, aphorism, Islam, Ibn Hazm

\section{Introduction}

In the history of philosophy, in addition to certain recognized ways of expressing philosophical thought, one can easily find works in their form less associated with academic philosophy, such as, for instance, philosophical dialogues popularized by Plato. Another and no less interesting way of expressing one's

TOMASZ STEFANIUK, habilitated doctor, Institute of Philosophy, Maria Curie-Skłodowska University in Lublin, Poland; address for correspondence: Instytut Filozofii UMCS, Pl. Marii CurieSkłodowskiej 4, PL 20-031 Lublin; e-mail: tomasz.stefaniuk@poczta.lublin.umcs.pl 
philosophical thought is aphorism, in which both form and expressed content are equally important.

Aphorism is a kind of expression that is not only concise, but also contains interesting thoughts, important, deep insights, etc. - being, therefore, "naturally" open to entering the field of philosophy. ${ }^{2}$ As masters of philosophical aphorism, both modern ${ }^{3}$ and earlier (especially ancient) ${ }^{4}$ philosophers can be mentioned. Apparently, the authors of philosophical aphorisms preferred to relate to issues from a similar (at least substantially similar) area of philosophical interests. Aphorists usually have had a good place in the field of philosophical ethics (moral philosophy), philosophical discussion of the complexity of human characters and life attitudes, general philosophical view on how society works ${ }^{5}$ and philosophy of life, broadly understood. ${ }^{6}$

The purpose of this article is to analyze and discuss the most important issues that Ibn Hazm - a medieval Arab-Muslim author - addresses in his treatise AlAhlāq wa-' '-Siyar fi Mudāwāt Al-Nufüs (Morals and Right Conduct in the Healing of Souls, hereinafter referred to as Al-Ahlāq wa-' 1 -Siyar), ${ }^{7}$ as well as, generally,

${ }^{2}$ Of course, not every aphorism is a philosophical one. It seems that in order for it to be recognized as such, it should first of all refer in its content to the area of interest to be found in philosophy, and thus - among other things - to issues such as the meaning of life, the acquisition of wisdom (and/or knowledge) by man, human existence (in general, philosophical terms), morality etc.

${ }^{3}$ Francis Bacon, Thomas Hobbes, Rene Descartes, Blaise Pascal, François de La Rochefoucauld, David Hume, Immanuel Kant, Arthur Schopenhauer, John Stuart Mill, Bertrand Russell, José Ortega y Gasset and Ludwig Wittgenstein, among others.

${ }^{4}$ For example, the following: Thales of Miletus, Pythagoras of Samos, Heraclitus of Ephesus, Protagoras of Abdera, Plato, Aristotle and many, many other. In addition, it is worth emphasizing that philosophical aphorism is not something only present in Western culture; as the authors of aphorisms, Lao Tze, Confucius, as well as some philosophers from the Arab-Muslim culture (e.g. Al-Kindi or Avicenna) can also be mentioned.

${ }^{5}$ Which, of course, did not always mean deep, academic analysis of society.

${ }^{6}$ When the latter is mentioned, it does not necessarily have to mean philosophizing as a way of life, endorsed by Lebensphilosophie (Wilhelm Dilthey or Henri Bergson), but rather simply focusing on human existence as a fundamental issue of philosophy, as well as expressing some philosophical advice to enable life in accordance with reason and nature, attaining the happy, tranquil life etc. As for ancient Greek thinkers with such an approach to philosophy, Democritus, Socrates, Aristotle, Epicurus or Stoics may be mentioned.

${ }^{7}$ For original, Arabic text see: Rasā'il Ibn Hazm al-Andalusī, ed. Iḥsan Abbas, vol. 1 (Beirut: AlMu'assasa al-'Arabiyya li-'1-dirasat wa-' 1 -nashr, 1987), 321-415. For Polish translation see: Janusz Danecki, Traktat o leczeniu dusz, kształceniu moralności i poskramianiu wad (Warszawa: Wydawnictwo Akademickie DIALOG, 1998). 
analysis of the philosophy presented there. An issue worth considering is also whether this work is a philosophical work at all - while it is undoubtedly an example of the Arabic-Muslim literature of that period (so-called adab literature); the more that Ibn Hazm himself was remembered primarily as a religious writer. It should be also examined whether this treatise was written mostly under the influence of religious (Islamic) content - or perhaps Ibn Hazm also used philosophical sources, e.g. classical Greek philosophy.

\section{Ibn Hazm and his legacy}

In the West, Ibn Hazm is undoubtedly one of the less well-known philosophers. The reason is probably not only the belonging to a different cultural circle, but also the much greater interest of Western researchers and readers in the legacy of the representatives of the 'classical' Arab philosophy (also called falsafa, among others Al-Farābī, Avicenna and Averroes), in Sufism, also in Al-Ġazālī (Lat. Algazel) - considered, for good reason, as the greatest representatives of the philosophical (Arab-Islamic) thought. In addition, the fact that Ibn Hazm was primarily a religious writer for whom philosophy was never a priority (which does not mean that he did not achieve significant, noteworthy results in this field) may have an additional impact here.

Abū Muhammad 'Alī ibn Aḥmad ibn Sa īd ibn Ḥazm (994-1064) - also known as Al-Andalusī, Az-Zāhirī̄ - was born in Cordoba (now Spain, then under Arab rule) and came from a wealthy and influential family. ${ }^{9}$ His grandfather and father were associated with the circles of power, serving Umayyad Caliph Hišām II. The late philosopher, in turn, thanks to his education and numerous talents, took part in the court life during the reign of Al-Manșūr ibn Abi 'Āmir (Almanzor), who was Grand Vizier to the last of the Umayyad caliphs, Hišām III.

${ }^{8}$ Al-Andalusī - (Arab.) Andalusian; Az-Zāhirī - (Arab.) proponent of Zahirism, see further in this article.

${ }^{9}$ For Ibn Ḥazm’s biography see, for instance: José Miguel Puerta Vílchez, “Abu Muhammad 'Ali Ibn Hazm: A Biographical Sketch," in Ibn Hazm of Cordoba: The Life and Works of a Controversial Thinker, eds. Camilla Adang, Maribel Fierro (Leiden: BRILL, 2012), 3-24. See also: Charles Pellat, "Ibn Hazm al-Andalusi," Journal of the Pakistan Historical Society 9, no. 2 (1961): 71-74; Muhammad Abu Layla, "An Introduction to the Life and Work of Ibn Hazm," Islamic Quarterly 1985, no. 29, 165-171. 
Ibn Hazm lived in the period of great cultural prosperity of Arab-Muslim Andalusia, but at the same time in the period preceding its decline, when Arabs and Berbers fought among themselves there. As a result of ongoing political disputes, at the beginning of the 11th century the Umayyad Caliphate of Iberia lost its unity, which meant the collapse of one central authority of Córdoba and the rise of smaller states, so called taifas (Arab. țāifa, plural țawā'if). ${ }^{10}$ During this difficult period Ibn Hazm stood on the side of the legal power of the Umayyads, and then suffered the consequences of this choice (the philosopher was, for instace, imprisoned many times). In the end, his experience with politics turned out to be disappointing. He decided to move to a home retreat, to settle away from the center of political events and write. ${ }^{11}$

Ibn Hazm - who represented traditional theology (Arab. al-atariya) ${ }^{12}$ - was and still is considered one of the most influential representatives of Zahirism (Arab. al-zāhirìyyah), i.e. one of Islamic schools of thought, or madhhab (Arab. madhab) of Islamic jurisprudence. ${ }^{13}$ The founder of Zahirism was Dawud AlZāhirī (815-883/4), who together with his followers expressed reliance on the outward (Arab. zāhir) meaning of terms and expressions found in the Qur'an and hadiths. Briefly speaking, the Zahirites were opposed to relying on philosophical reason when developing the principles of Muslim religious law and formulating the principles of faith. This did not mean, however, that they condemned rationalism completely. In connection with the above, it should be emphasized that Ibn Ḥazm has always been considered mostly a religious writer - which, however, cannot cancel his noteworthy achievements in other fields, except religion, namely achievements in the fields of literature and philosophy.

${ }^{10}$ For history of Arab Andalusia see, for instance: Mahmoud Makki, "The Political History of alAndalus (92/711-897/1492)," in The Legacy of Muslim Spain, ed. Salma Khadra Jayyusi (Leiden: BRILL, 1992): 3-87.

${ }^{11}$ Perhaps it is worth drawing a general analogy here, making his biography similar to the biography of the later Niccolò Machiavelli. They both were taking part in court life, engaged in politics, then withdrawing from it - in order to share the insights and conclusions they reached in the result of difficult but also interesting life experiences.

${ }^{12}$ Its main goal was to reject kalam, or rationalistic Islamic theology, at least partly based on philosophical methods, in favor of strict textualism - in interpreting the source text of Islam. Interestingly, his traditionalist approach did not prevent him from considering the possibility of prophecy among women.

${ }^{13}$ For legal aspects of Ibn Hazm's thought, see, for instance: Adam Sabra, “Ibn Hazm’s Literalism: A Critique of Islamic Legal Theory," in Ibn Hazm of Cordoba, eds. Adang, Fierro, 97-160. 
Ibn Hazm wrote about 400 papers, of which only a small part survived, which was due to the fact that the rest was destroyed (burnt in Seville) by his opponents living in Andalusia. As Josep Puig Montada rightly notes, Ibn Hazm is an author whose achievements are sometimes difficult to easily classify: "In viewing Ibn Hazm's huge and diverse literary production, we are not certain how we ought to classify him, using the standard categories. He is a Koran expert, a traditionalist, a theologian, a historian, and above all, a polemicist". ${ }^{14}$

The first group of Ibn Hazm's works are these devoted to religious studies: Islamic religious law and theology. One of his most important work of in this group is Kitab al-Muhallā bi-1-Athär (The Book Ornamented with Traditions, or The Adorned Treatise, or al-Muhallā), in which Ibn Hazm raised issues of jurisprudence (or fiqh), but also touched the matters of Muslim creed. He did not limit himself, however, to presenting his own school's position only, or to religious apologetics, but also devoted himself to pioneering work in the field of comparative religion, which in his case was religiously motivated. He wanted to defend what he thought was Muslim orthodoxy, at the same time, showing the mistakes of other religions (Christians and Jews) and certain religious sects. ${ }^{15}$ In his opinion, sects that only referred to Islam in fact had nothing to do with it (as a sect, or more precisely, as apostates, he considered, for example, Shiites). ${ }^{16}$ In addition, he attacked the views of the followers of Ash'arism (Arab. al-'ašariya) and Mu'tazilites (Arab. al-mu'tazila), which he also considered incompatible with Islam and erroneous. ${ }^{17}$ Ibn Hazm's famous work on these issues was Al-Fișal fi-' IMilal wa-' I-Nihal ( The Separator Concerning Religions, Heresies and Sects, or AlFișal). ${ }^{18}$ This work aroused considerable controversy during the philosopher's lifetime, primarily because of the criticism contained in it of certain religious trends

${ }^{14}$ Josep Puig Montada, "Reason and Reasoning in Ibn Hazm of Cordova (d. 1064)," Studia Islamica 2001, no. 92: 165-185.

${ }^{15}$ For Ibn Hazm's views on religion and sects see, for instance: Jessica A. Coope, "With Heart, Tongue, and Limbs: Ibn Hazm On the Essence of Faith,” Medieval Encounters 6, issue 1-3 (2000): 101113 .

${ }^{16}$ See, for instance, Israel Friedlaender, "The Heterodoxies of the Shiites in the Presentation of Ibn Hazm," Journal of the American Oriental Society 1908, no. 29: 1-183.

${ }^{17}$ See, for instance, Sabine Schmidtke, "Ibn Hazm's Sources on Ash'arism and Mu'tazilism," in Ibn Hazm of Cordoba, eds. Adang, Fierro, 375-402.

${ }^{18}$ Ibn Ḥazm, Kitab al-Fịsal fi al-milal wa-al-ahwa wa-al-nịhal (n.p.: Ulan Press, 2012). 
within Islamic society (such as Ash'arism), which at that time had many supporters. ${ }^{19}$

Another group of Ibn Hazm's works are literary and philosophical works, as well as those devoted to logic. Arab philosopher strongly defended logic - the knowledge of which, he believed, is necessary for conducting religious studies in the right way. And he considered relying on logic in religious research to be particularly important in times when the prophet is no longer present, and when the faithful cannot simply approach him and ask; in such a situation, the they should rely on their own intellect. Such an attitude to logic (understood as an indispensable element of religious education) indicates that the Arab philosopher was a rationalist, despite the fact that he clearly took orthodox position in various religious matters. ${ }^{20}$ In addition, Ibn Hazm preached empiricism, believing that the source of all knowledge is the sense perception. ${ }^{21}$ This fact alone deserves the careful attention of the historian of philosophy, for we refer here to a period (the Middle Ages) in which empiricism was not a common position.

It remains to some extent an open question of how and to what extent Ibn Hazm knew Greek philosophy, and perhaps - to put it more precisely - Greek philosophers, especially the most important ones, whose views show (at least) formal similarity with his own philosophy. Undoubtedly, the knowledge of philosophy in Andalusia was initially weak and limited rather to logic. Studying the biography of Ibn Ḥazm, however - from which, as José Miguel Puerta Vílchez writes, we cannot get too much information about his intellectual formation ${ }^{22}$ - we find out that among his many teachers one showed interest in philosophy. It was, as

${ }^{19}$ Adam Sabra, “Ibn Hazm's literalism: A critique of Islamic legal theory," in Ibn Hazm of Cordoba, eds. Adang, Fierro, 97-160.

${ }^{20}$ On Ibn Hazm and Aristotle's logic see, for instance: Rafael Ramon Geurrero, "Aristotle and Ibn Hazm. On the Logic of the Taqrib," in Ibn Hazm of Cordoba, eds. Adang, Fierro, 403-416. See also: Anwar G. Chejne, "Ibn Hazm of Cordova on Logic," Journal of the American Oriental Society 104, no. 1 (1984), Studies in Islam and the Ancient Near East Dedicated to Franz Rosenthal: 57-72.

${ }^{21}$ Although Ibn Hazm postulated empiricism, he believed, as Vílchez rightly points out, that "the noblest knowledge is knowledge of the Revelation through its texts" (see: José Miguel Puerta Vílchez, "Art and Aaesthetics in the Work of Ibn Hazm," in Ibn Hazm of Cordoba, eds. Adang, Fierro, 255); in other words, "God's commands cannot be deduced; so, they must be learnt and taught" (see: Gabriel Martinez-Gros, "Ibn Ḥazm on History: A Few Remarks," in Ibn Hazm of Cordoba, eds. Adang, Fierro, 92).

${ }^{22}$ Rafael Ramón Guerrero, "Aristotle and Ibn Hazm. On the Logic of the Taqrïb," in Ibn Hazm of Cordoba, eds. Adang, Fierro, 406-407. 
Rafael Ramón Guerrero writes, Abū 'Abd Allāh Muḥammad ibn al-Ḥusayn (or al-Ḥasan) al-Madhhijīi, also known as Ibn al-Kinānī or al-Kattānī, who he passed on to the future philosopher knowledge of logic, perhaps based on the Arab summaries of Aristotle's work on logic functioning at that time. ${ }^{23}$ One should not, therefore, doubt that Ibn Hazm knew Greek philosophy. Some modern researchers, Anwar G. Chejne for example, emphasize that he even was „enthusiastic defender of the sciences of the Ancients [...] which comprised logic, mathematics, astronomy, medicine, and other sciences" 24 - and this obviously means that he knew the views of the most important ancient philosophers, even if he knew them second-hand. ${ }^{25}$

Ibn Hazm also devoted some of his work to ethics, morality and, in general, human affairs. Two works from this group deserve special attention: Tawq alHamāmah (The Ring of the Dove $)^{26}$ and the already mentioned treaties Al-Ahlāq wa-' I-Siyar. As for the first of these works, it was a partly versed work, dedicated to love and lovers. Referring to this topic was obviously not new in Arabic literature, nevertheless Ibn Hazm presented an innovative approach - firstly referring to personal experiences, and secondly being an insightful "psychologist". In addition, it should be added that Ibn Hazm referred to philosophy in his already mentioned Al-Fișal fi-' I-Milal wa-' I-Nihal, where he not only discussed various religious sects or schools, but also defined his attitude to the views of some Greek philosophers. He also wrote poetry.

${ }^{23}$ Vílchez, “Abū Muhammad 'Alī azm: A Biographical Sketch,” in Ibn Hazm of Cordoba, eds. Adang, Fierro, 14.

${ }^{24}$ Anwar Chejne, "Ibn Hazm of Cordova on Logic," 57.

${ }^{25}$ Rafael Ramon Guerrero also mentions that the Andalusian writer probably knew Aristotle only secondhand: "[...] The relationship with the works of the Greek philosopher is not direct, but indirect, possibly originating in some summary or oral transmission"; see Guerrero, "Aristotle and Ibn Hazm," 409. Also Vílchez - referring to Ibn Hazm's work entitled Kitāb al-Balāgha - writes that he did not know well (i.e. through contact with source texts) the philosophy of Aristotle: "He shows that he is not familiar with the Greek philosopher's Rhetoric nor with his Poetics"; Vílchez, "Inventory of Ibn Hazm's Works," in Ibn Hazm of Cordoba, eds. Adang, Fierro, 690. See also Mohammad Sharif Khan, Mohammad Anwar Saleem, Muslim Philosophy and Philosophers (Dehli: APH Publishing, 1994), 38-44.

${ }^{26}$ See: Lois A. Giffen, "Ibn Hazm and the Tawq al-Hamama," in The Legacy of Muslim Spain, ed. Salma Khadra Jayyusi (Leiden: BRILL, 1992): 420-442. 


\section{Al-Ahlāq wa-' I-Siyar as a philosophical treatise}

Another work by Ibn Hazm - in the area of literature and philosophy - is his treatise Al-Ahlāq wa-' 1 -Siyar. ${ }^{27}$ This work avoided total destruction (after the conquest of Andalusia by Christians) primarily because its author gained great popularity also in the Muslim East, thanks to which this work has been preserved in several manuscripts. It was also published in the modern era and translated it into Spanish, French or Polish. ${ }^{28}$

This is not extensive work. On the contrary, it is rather short and is divided into eleven chapters. In terms of structure, this work may seem a bit chaotic at first, which was the usual feature of adabliterature, as Danecki rightly points out. ${ }^{29}$ In the case of this treaties, such a relative chaos manifests itself mainly in the changeability of the topics discussed. However, after a closer look at AlAhläq wa-'I-Siyar, the sense of chaos disappears.

It seems that the most important issue raised by Ibn Hazm in his Al-Ahlāq wa-' 1 -Siyar is the search for meaning in life. The author already addresses this and similar issues in the first chapter of his work - emphasizing that only striving for eternal life can be considered the most noble goal. The other ten chapters were devoted, among others, to human nature, human characters, the need to work on oneself, or to relationships with other people (living in society, being part of it etc.). The titles of these chapters themselves say a lot about the subject and nature of the work: About the Healing of Souls and the Repair of Condemnable Character Traits, On Morality and Ways of Acting, About Dealing with People etc.

It is hard not to get the impression that all issues related to morality were extremely important to Ibn Hazm. This is additionally evidenced by the fact that in this treatise, in Chapters III and VIII, he even presented several quasi-definitions of terms relevant to ethics, such as selflessness ("The virtue of the soul consisting of courage and generosity"), generosity ("A special kind of courage"),

${ }^{27}$ Al-Ahlāq wa-'l-Siyar can be called a treatise, although we do not mean a simple philosophical treatise here, rather a work shorter than a typical book - which in Arabic philosophical literature was most often called treatise (Arab. risāla), not a book (Arab. kitāb).

${ }^{28}$ The treatise was issued in the modern era in 1908 in Cairo. For more information see, for instance: Alois Richard Nykl, "Ibn Hazm’s Treatise on Ethics." The American Journal of Semitic Languages and Literatures 40, no. 1 (1923): 30-36. See also: Janusz Danecki, "Wprowadzenie," in O leczeniu dusz i poskramianiu wad, ed. Janusz Danecki (Warszawa: Wydawnictwo DIALOG, 1998), 11.

${ }^{29}$ Danecki, "Wprowadzenie", 9-10. 
temperance, justice and others. ${ }^{30}$ Some modern scholars therefore believe that $\mathrm{Al}$ Ahlāq wa-'I-Siyar is somehow the key work of an Arab philosopher, and that also "is very valuable for the better understanding of Tauk al Hamama", one of Ibn Hazm's best known works. ${ }^{31}$

What distinguishes Al-Ahlāq wa-'I-Siyar from Western (European) philosophical aphorisms is undoubtedly the "Islamic character" of the treaties. This cannot be surprising, given the fact that this work was created in the Middle Ages in a culture very strongly dominated by religious content, in this case Islam. The fact that Ibn Hazm's work was written in a clearly defined cultural environment is evidenced by the very beginning of the work where the name of God is mentioned, and then followed by (typical for works from that era, coming from the Arabic-Muslim cultural circle) a short praise for God, combined with an expression of respect for Prophet Muhammad. ${ }^{32}$ Strong ties linking the treatise with Islamic culture are also evidenced by the intention of Ibn Hazm, also expressed at the beginning of the work, for writing for the satisfaction of God, not for the purpose of seeking applause among people. ${ }^{33}$

These features of Ibn Hazm's treatise alone show that the influence of Islamic religious sources is clear here, but it is even more strongly testified by the very content of the work, above all by the call expressed in it to devote life to God and to act for the sake of ultimate happiness in paradise [Arab. bi-1- amal li-l-ahira ${ }^{34}$ ]. In the early passages of this treatise, Ibn Hazm writes, for example: "I have found that the pursuit of a better life in that world is free from all unrighteousness [...] and leads the best way to get rid of worries". ${ }^{35}$ In another passage we read: "A man seeking evil resembles Satan. A man striving for fame and violence is like a wild animal [...]", while "a man striving for eternal life is like an angel". ${ }^{36}$

Such religiously oriented remarks do not mean, however, that in $A l-A \underline{h} l \bar{q} q$ wa-' I-Siyar it is difficult to look for what we usually find in philosophical works. On the contrary; according to Ibn Hazm, the most important matters should be based on reason (which does not exclude, in his opinion, a life centered on God).

\footnotetext{
${ }^{30}$ Rasa'il Ibn Hazm al-Andalusi, ed. Ihsan Abbas, 348-351.

${ }^{31} \mathrm{Nykl}$, Ibn Hazm's Treatise, 35.

${ }^{32}$ Rasa'il Ibn Hazm al-Andalusi, ed. Ihsan Abbas, 333-334.

${ }^{33}$ Ibidem.

${ }^{34}$ Ibidem, 340-341.

${ }^{35}$ Ibidem.

${ }^{36}$ Ibidem, 343.
} 
But when Ibn Hazm's rationalism is mentioned, it does not necessarily have to mean that his position was close, for instance, to the position of Mutazilites (a school representing even extreme rationalism in relation to all issues related to religion). Being a supporter of Zahirism, Ibn Hazm rejected kiyas, i.e. rational inference by analogy and thus reaching conclusions in the field of theology and religious law. But that still doesn't mean that even in his approach to religion (not just life) he was not a rationalist; the more that rationalism as a certain life attitude and approach to sources of knowledge, as well as an approach to the foundations of human moral behavior, is something complex and extensive, which actually includes a multitude of various attitudes and approaches; for example, his praise of logic (necessary even for religious studies) has already been mentioned. Interestingly, in addition to being a rationalist (to some extent and in some sense of the term), the he also supported empiricism; and the very fact of proclaiming empiricism in that historical period deserves, perhaps, more in-depth attention in the study of the history of philosophy. According to him, it would be inappropriate to rely on anything but sensory experiences and sensations, which then become the subject of rational analysis.

Ibn Hazm was also a philosopher in the sense that his views - regarding human existence, the diversity of human characters and attitudes, life in society, etc. - were the result of his own thoughts and criticism, and not just the fruit of, for example, an analysis of Islamic source texts, Quran and hadiths (if that were not the case, he should be described as a "only" religious writer). The views expressed in Al-Ahläq wa-'I-Siyar should be, therefore defined as the philosophy of life in the broadest sense possible. For example, by making rational analysis, as well as by using certain "material" taken from own life experience, Ibn Hazm notes that people pursue different goals (such as wealth, social position, etc.), but all these efforts are ultimately in vain. This is because in this life man must lose something of the things he is trying to achieve, or even stay with nothing. In other words, any hope will ultimately bring sadness, because either one will not be able to fully realize own plans, or in time he will no longer want to pursue these goals as before. ${ }^{37}$ As it is not difficult to guess, joy and satisfaction arising from choosing the path leading to God seem to be, according to Ibn Hazm, something more persistent, lasting and firm; however, again, this is the result of the author's philosophical

${ }^{37}$ Rasa'il Ibn Hazm al-Andalusi, ed. Ihsan Abbas, 337-338. 
reflections, not just a simple analysis of Quranic verses. In other words, this is merely a conclusion - of course completely coincident with the content found in the Quran or hadiths; nonetheless, his observations (here, regarding human endeavors in this life and, ultimately, their fruitlessness) are a manifestation of his own philosophical search. Ibn Hazm's philosophy draws very clearly from his life experiences, and this feature has been noticed by many contemporary researchers of the legacy of the Arab philosopher, including A. R. Nykl. According to Nykl, Ibn Ibn Hazm's use of auto-analysis (or auto-reflection) as a method - particularly evident in Chapter III of this work - resembles the method used by Al-Ghazali, Augustine, Petrarch or Montaigne. ${ }^{38}$ In short, Ibn Hazm - like the philosophers mentioned above, as well as, for example, Nicolo Machivelli or François de La Rochefoucald - first gained life experience and only then formulated their philosophy. It is clearly visible that the author of Al-Ahläq wa-' 1 -Siyar gives advice from the position of someone who has already seen and understood a lot in his life. This is evidenced by the style of some sentences and some specific passages. For example, at the beginning of the treaties, Ibn Hazm mentions that - over the years, with the passing of time - he has gotten to a lot of thoughts and now prefers to meditate on change of fate than, like other people, indulge exclusively in various pleasures of life or increase his wealth. ${ }^{39}$ In any case, reflection on the variability of fate and human existence often (in this work) takes the form of advice that the author gives to his readers. These advice, especially regarding dealing with people, is sometimes surprisingly specific. In chapter XI we read, for example: "Beware of asking stubborn people and asking questions to lofty people who want to be right, although their knowledge is small." ${ }^{40}$ In Chapter IV, Ibn Hazm writes: "If you want to give advice, do so in a secluded place, taking care that your voice is gentle." ${ }^{41}$ Referring to the most specific matters, when giving advice to readers, should be considered the next distinctive feature of Al-Ahlāq wa-' I-Siyar.

At the same time, analyzing the content of this work, it is difficult not to get the impression that its author not only speaks from the position of someone who has already gained a lot of life experience, but that he also speaks like someone who has managed to see what others have failed. Ibn Hazm performs some kind

\footnotetext{
${ }^{38} \mathrm{Nykl}$, Ibn Hazm’s Treatise, 32-33.

${ }^{39}$ Rasa'il Ibn Hazm al-Andalusi, ed. Ihsan Abbas, 333-334.

${ }^{40}$ Ibidem, 412.

${ }^{41}$ Ibidem, 327-328.
} 
of "demystification" (or at least he thinks so) when he writes about people, human behavior, and finally about living among people. He managed - as he believes at least - to look behind the veil of illusion. He "decoded" human reality, he was not fooled by the "game of appearances". For example, in Chapter VIII, entitled About not giving in to appearances, he writes that "a reasonable person should not judge anyone on the basis of external symptoms". ${ }^{42}$ Such an attitude - clearly present in Al-Ahlāq wa-' l-Siyar - is expressed in many passages of the treaties. For example, we read there that "from losing a friend, it is more unfortunate to have a friend with bad intentions,"43 and that "a man who speaks loudly about bad deeds is the one who most easily acts so." ${ }^{44}$ Ibn Hamz also writes, in another passage, that "to reproach a friend is like making a metal cast: either it will work or you will have to throw it out," ${ }^{5}$ and that "the first of those whom you have given goodness will hurt you and will act against you". ${ }^{46}$ According to him, a wise person should not be deceived by "friendship gained in the days of success." ${ }^{37}$ Such phrases clearly show that the author was convinced of the exceptional insight of his own mind, regarding himself as the one who managed to look "behind the veil of illusion" and discover "how things are actually." His conclusions are rather pessimistic and, in essence, come down to rejecting the idealized, utopian image of man and society. It is no longer important what people should be, but what they really are. This approach, at least in part, makes Ibn Hazm's philosophy similar to the philosophy of some European philosophers of the modern era, for example to the already mentioned Machiavelli (politics is not about any higher ideals), De La Rochefoucauld (what people present as their own virtue, most often is a hidden vice), Thomas Hobbes and Bernard Mandeville (people are by no means good, altruism does not exist), not forgetting Schopenhauer (people only think that they are ruled by reason and that they are free entities).

That what also distinguishes Ibn Hazm's treatise are his insightful psychological observations, as well as the ability to express them in excellent literary form. For example, the author Al-Ahlāq wa-'I-Siyar writes: "I have found that

\footnotetext{
${ }^{42}$ Ibidem, 407-408.

${ }^{43}$ Ibidem, 405-406.

${ }^{44}$ Rasa'il Ibn Hazm al-Andalusi, ed. Ihsan Abbas, 405-406.

${ }^{45}$ Ibidem, 359.

${ }^{46}$ Ibidem, 360-361.

${ }^{47}$ Ibidem, 351-352.
} 
people are more likely to share their feelings rather than wealth." ${ }^{38}$ In another passage he mentions that "long lasts worries of a man who is angry with the truth." 49 In this work, of course, we will find many similar, accurate, deep and sometimes surprising observations.

Ibn Hazm, as the author of the treatise, is also a moralist, and an uncompromising one (this uncompromising attitude has, in fact, caused him, as we know from his biography, some troubles in his life). ${ }^{50}$ This is testified by his many remarks and observations, including those in which he writes that customs as such - if they are immoral or irrational - must be destroyed. Needless to say, his moral teachings were clearly religiously oriented, focusing on fixing one's character and perfecting behavior (above all, own). According to the Andalusian philosopher, such actions should be undertaken with the right intention, i.e. for God's satisfaction and for the sake of the next life. ${ }^{51}$

\section{The diversity of human characters and the search for meaning in life, according to Ibn Hazm}

Author of Al-Ahlāq wa-' 1 -Siyar deals with two main topics in his work. First, he draws attention to the search for a meaning of life, and this - according to him - is associated with human activity and achieving certain goals in life. Another important issue, or rather a group of issues, is the diversity of human characters and aspirations, and that in turn is related to the diversity of interpersonal relationships in society. Man is, therefore, regarded here primarily as the subject of action, and secondly as someone who gets involved in relationships with other people. $^{52}$

${ }^{48}$ Ibidem.

${ }^{49}$ Ibidem,482-483.

${ }^{50}$ Ibidem, 355-356.

${ }^{51}$ Ibidem.

${ }^{52}$ Vilchez mentions that the Arab philosopher describes man primarily as the subject of action: "Although the human being cannot create anything from nothing, since this does not form part of the nature of things but is an exclusive attribute of the Creator, he does however still have considerable room to order his language, his knowledge and his art;" José Miguel Puerta Vílchez, "Art and Aaesthetics in the Work of Ibn Hazm", in Ibn Hazm of Cordoba: The Life and Works of a Controversial Thinker, eds. Camilla Adang, Maribel Fierro (Leiden: BRILL, 2012), 267. 
Reflecting on how people relate to their lives and how their life plans and aspirations differ, Ibn Hazm is trying to find out if there is something that connects each of them. According to him, that thing is a desire to drive away worries, or in other words, a willingness to gain peace and contentment in life. As we read in chapter I: "I was looking for a goal that would be recognized and praised by everyone (Arab. garad yastawī an-nasu kulluhum). I found only one such goal. It is warding off worries (Arab. wa huwa tard al-hamm)." ${ }^{53}$

Of course, Ibn Hazm was not the first philosopher interested in practical philosophy who made happiness, as well as driving away worries and troubles, one of the main issues in his research. These issues were addressed by many Greek philosophers, especially those who dealt with ethics and philosophical anthropology (the same can be said, incidentally, about their followers in the field of Arab-Muslim philosophy: Al-Kindī, Al-Farābī, Avicenna and others). Ibn Ḥazm, however, did not exactly follow the path marked by his Greek predecessors; it could not be otherwise, because the monotheistic (Islamic, to put it more precisely) perspective was fundamentally different from the perspective of Greek philosophers. In Islam, the world is treated as God's work and something that is simply owned by the Creator - including people. In one of the verses of the Quran we read that God created people only to worship him [Arab. illa li-ya budūn] ${ }^{54}$ - which is understood as broadly as possible, because "worship" here [Arab. 'ibāda] means not only religious acts in a narrow sense (e.g. prayers, fasting), but in general all human life subordinated to God's will. Therefore, it should not be surprising that in the ethics and philosophical anthropology of the Andalusian philosopher - who was very clearly influenced by Islamic source texts - these issues become key points. Ibn Hazm writes about getting rid of all worries by striving to please God and in order to gain the best status in the afterlife. As we read in his treaties, "for a wise person, the only value worthy of his soul [i.e. worthy of himself] is paradise; everything other than serving God is vanity and stupidity." ${ }^{55}$ It is not surprising that Ibn Hazm - for dealing with worries - he presents measures that are not the same as those of Greek philosophers (e.g. apatheia or atharaxia, as postulates of practical philosophy). His philosophical search for happiness and avoidance of worries was

\footnotetext{
${ }^{53}$ Rasa'il Ibn Hazm al-Andalusi, ed. Ihsan Abbas, 336.

${ }^{54}$ See: Quran 51:56.

${ }^{55}$ Rasa'il Ibn Hazm al-Andalusi, ed. Ihsan Abbas, 338.
} 
always situated in the human-God relationship, as well as in worldlylife-ultimate life relationship, as it was the case in Christian philosophy. ${ }^{56}$

He does not stop, however, at merely presenting a strictly Islamic point of view, that is, the point of view to be found in the Qur'an and hadiths. The author Al-Ahlāq wa-'I-Siyar connects the postulate of submission to God and acting for the sake of future life (in paradise) very clearly with a call - typical for the tradition of Greek philosophy, found in Plato or Stoics, for instance - to master the human soul through reason, and especially to convey power over emotions to reason. ${ }^{57}$ The postulate of relying on reason is a key ethical postulate that we find on the pages of the discussed treaties, and the Arab philosopher devotes a lot of attention to this issue in his work. For example, in Chapter III, he gives advice that the Stoic would give: "Get used to what you do not like." ${ }^{58}$ Like the Stoics, for example, he believes that man in his actions should be guided by the intellect, and should not simply succumb to whims. Only average people, or masses - for whom Ibn Hazm does not have much respect - follow whims and give their souls over to emotions. He writes, for example, that "when [in man] lust arises [...], worries, thoughts and anger arise, and this can often lead to loss. ${ }^{\prime 59}$ He treats being submissive to desires and whims as the opposite of relying on reason - and this should be done to improve - or "heal" - own character. The only difference between his position and that of the Stoics (or some other Greek philosophers) comes down to motivation: according to the author of Al-Ahlāq wa-' l-siyar, this is done to please Maker of man.

${ }^{56}$ Ataraxia (Greek: $\alpha \tau \alpha \rho \alpha \xi_{\llcorner} \alpha$ ) - in ancient philosophy, a state of no confusion, unwaveringness, balance of spirit, ideal of inner peace of man. The state achieved by getting rid of excessive desires and the fear of death and suffering, and finding spiritual joy that originates from reason and virtue. The term is characteristic of the philosophy of Cynicism, Stoicism, Skepticism, also present in Epicureanism. Apatheia (Greek: àं $\dot{\alpha} \theta \varepsilon ı$ ) - in Stoicism, state of mind in which one is not disturbed by the passions. See, for instance, William Keith Chambers Guthrie, A History of Greek Philosophy, vol. 2: The Presocratic Tradition from Parmenides to Democritus (Cambridge: Cambridge University, 1965), 493.

${ }^{57}$ Several contemporary researchers mention that Ibn Hazm's ethical views resemble ethics of the Stoics. Vichez, among others, points out: "In this work Ibn Hazm attempts to reflect his attitude to life and society, with a rather stoical cast, pointing out the virtues and vices which occur in human nature, praising the former and execrating the latter"; see: José Miguel Puerta Vílchez, "Inventory of Ibn Hazm's Works," in Ibn Hazm of Cordoba: The Life and Works of a Controversial Thinker, eds. Camilla Adang, Maribel Fierro (Leiden: BRILL, 2012), 722.

${ }^{58}$ Rasa'il Ibn Hazm al-Andalusi, ed. Ihsan Abbas, 347.

${ }^{59}$ Ibidem, 371. 
Referring to these issues, the Arab philosopher - as has already been mentioned - relies on acquired life experiences, desiring ALSO to share his own wisdom. In Chapter III, for example, entitled Fighting vice, he writes: "I had many defects which I constantly fought [...]. God has given me grace and I have managed to control most of them. [...] These flaws included the desire to attract people and excessive anger. [...] These flaws also included exaggerated malice. [...] Reason criticized me for all my flaws, until I got rid of all of them." ${ }^{\prime 60}$ Among his other disadvantages, which he fought, he also mentions, among others, the pursuit of fame and greatness, an excessive sense of dignity or frequent resentment. ${ }^{61} \mathrm{At}$ the same time, it is hard not to get the impression that Ibn Hazm himself feels satisfaction because of the work done by himself, although he also notices that man is unable to do everything - for we are already born with some character traits or "tendencies," which come from God directly. As he writes, "happy are those whose souls are prone to virtues and obedience [to God] [...]. Poor are those whose soul is prone to vices and disobedience [...]. We are dealing here only with God's will."62

Ibn Hazm's attitude does not seem to differ fundamentally from the attitude of many Christian philosophers - living in the Middle Ages and later, e.g. Blaise Pascal - who, seeing the highest value in a life devoted to God, tried to address these issues rationally and present some arguments providing just such a choice. However, in the case of the Andalusian author, it is significant that he very clearly emphasized the importance of knowledge and reason which, according to him, are necessary to choose the right way of life, as well as for "repairing" own character. He writes, for example - expressing the praise of knowledge, typical for the Arab-Muslim elites of that era, and at the same time contempt for the uneducated masses - that "if even the only advantage of knowledge was the fear and respect of fools [Arab. al-ğihāl] and the love and recognition of scholars [Arab. al'ulamā] , that would be reason enough to strive for it." ${ }^{63} \mathrm{He}$ also writes that "a wise person may not be lucky in achieving his goal, but it is unacceptable for a fool to achieve his goals." ${ }^{64}$ In another passage we read that "a man distant from the

\footnotetext{
${ }^{60}$ Rasa'il Ibn Hazm al-Andalusi, ed. Ihsan Abbas, 324-325.

${ }^{61}$ Ibidem, 325-327.

${ }^{62}$ Ibidem, 338-339.

${ }^{63}$ Ibidem, 343.

${ }^{64}$ Ibidem, 348.
} 
affairs of science cannot possess virtues unless his nature is unusually pure and noble." ${ }^{65}$ Undoubtedly, a strong attachment to knowledge and science was something that all Arab-Muslim philosophers preached, very often presenting also certain elitism, namely, emphasizing the superiority of educated people (or elites) over "the crowd" (or "common people"). However, this superiority was never related to the status of assets, but only to the attitude to knowledge and education. ${ }^{66}$ Such an approach clearly resembles the position of earlier Stoics, also proclaiming elitism and not directing their moral teachings to everyone (or at least being aware that they are not directed at the mass audience) ${ }^{67}$ The elitism of an Andalusian author sometimes transforms itself into misanthropy. In some fragments of his work, Ibn Hazm manifests (especially towards the crowd, and towards the uneducated masses) a clearly "aristocratic" attitude - but not aristocratic by lineage, rather by spirit and intellect. In Chapter III, for example, he writes: "Who spends time among people, he is not lacking in worries that bring pain to his soul, [...] no shortage of anger burning his heart." 68

To sum up this fragment of considerations, it should be emphasized that according to Ibn Hazm, knowledge makes man better; it also makes life choices more rational and leads to more favorable (also from a religious perspective) results. As he writes in Chapter III: "In developing virtue [Arab. fí istímāl al-faḍàil], knowledge brings invaluable benefits ${ }^{69}$; developing a rational life attitude means therefore, at the same time, developing own morality. Of course, such a moral philosophy is most strongly associated with ethics proclaimed by Socrates. As for Ibn Hazm, in his Al-Ahlāq wa-' l-Siyar he writes: "Reason is to skillfully use humility and virtues, which means taming vice and rebellion"70; and he would not be himself if it was limited only to general statements. The advice he gives are sometimes extremely specific. For example, in Chapter VIII he writes: "It has nothing to do with reason [...] - stoking people and agreeing on vain or shameful things, pleasing to those we are stroking, being cunning in acquiring wealth,

\footnotetext{
${ }^{65}$ Ibidem, 346.

${ }^{66}$ Danecki, "Wprowadzenie," 9.

${ }^{67}$ Rasa'il Ibn Hazm al-Andalusi, ed. Ihsan Abbas, 348.

${ }^{68}$ On the convergence of the Arab philosopher's views with the ethics of the Stoics, see for example: Montada, "Reason and Reasoning," 178.

${ }^{69}$ Rasa'il Ibn Hazm al-Andalusi, ed. Ihsan Abbas, 346.

${ }^{70}$ Ibidem, 378.
} 
achieving fame by neglecting nobility." ${ }^{\prime 1}$ As if concluding considerations on the positive impact of rationalist attitude on the formation of human morality, he writes in the final fragments of Chapter IX: "Reason is the foundation on which the walls of morality were built." 72

Ibn Hazm refers to all issues that are related to human characters and morality sometimes only descriptively, and sometimes also normatively, clearly defining what he thinks is commendable. According to him, the most important thing is to work on own character - or, in other words, to repair (or heal) own soul. Author of Al-Ahlāq wa-' l-Siyar is not only a philosopher but also a philosophizing moralist. Referring to human characters and morals, he clearly emphasizes that everyone should start making this world better with improving own self, and the first step to this is the realization by man that he is imperfect and that, therefore, he should not be too haughty. Ibn Hazm writes, for example, "Who is happy about being able to lift weights, let him remember that a donkey can lift much more." ${ }^{\text {73 }}$ In another passage we read: "It is amazing that thinking beings are proud of the qualities in which they are surpassed by non-thinking beings," and also that "who rejoices that he can run quickly, let them know that the dog and the hare are faster than him"74 and so on. The following excerpt from this treatise can be considered a kind of conclusion of these considerations: "Is there anything to enjoy and boast, since the animals are better than us in all this?"75 Looking for human uniqueness - in ancient philosophy and then in philosophy from the Arab-Muslim cultural circle - it was most often found that animals, unlike humans, do not participate in moral development, and also that rationality is the distinguishing feature of man. Ibn Hazm followed this path, stating that "one can enjoy the insight [of his mind], knowledge and beautiful works, because in this none of [...] animals can match us." 76

Author of Al-Ahlāq wa-'1-Siyar devotes a lot of attention to human nature (although he rarely writes directly about the nature of man), and his research and thoughts on all related issues clearly resemble the earlier philosophy of

\footnotetext{
${ }^{71}$ Ibidem, 379.

${ }^{72}$ Ibidem, 403.

${ }^{73}$ Ibidem, 395-396.

${ }^{74}$ Rasa'il Ibn Hazm al-Andalusi, ed. Ihsan Abbas, 340.

${ }^{75}$ Ibidem, 395.

${ }^{76}$ Ibidem, 340-341.
} 
the Stoics. It is worth mentioning that the influence of the stoic ethics on the position of Ibn Hazm has already been researched by contemporary Western authors. According to Josep Puig Montada, for instance, "the presence of Stoic thought in Islamic philosophy and thought in general is a long accepted phenomenon." 77 As Montada writes, Ibn Hazm was influenced by Stoic moral thought, and he "could easily have absorbed Stoic influence through the Latin tradition of the Mozarab church, a circumstance that does not exclude his reception of Stoic moral ideas transmitted by written Arabic literature." ${ }^{\text {78 }}$

Ibn Hazm conducts his considerations just like the Stoics: man should first recognize his nature and then act in harmony with it - which, in turn, according the author of Al-Ahlāq wa-'I-Siyar (as well as according to the Stoics) means above all rationalism. Man is, at least potentially, a wonderful creature, but - as has already been pointed out - not because of his body and its qualities, but because of his reason and the possibility of moral self-improvement ${ }^{79}$; and it is this (potential) morality and (potential) rationality that best define the nature of man. At the same time, however, we should also remember about our weakness and imperfection, which are also part of human nature; only such an approach allows us to improve own morality and own behavior. Referring to these issues the author writes, for example, in chapter IX:

Whoever feels admiration for himself, let him think about his vices. [...] If you admire your mind, remember all the bad thoughts that came to your mind. [...] If you admire your goodness, think [...] about your own sins and deficiencies. [...] If you are delighted with your knowledge, think that you have no merit in it, because it is only a gift from God. [...] If you brag about the fact that you come from noble ancestors, know that you shall not use their nobility if you are not noble yourself. [...] If you are proud of your body, think that the mule, donkey and bull are stronger than you. ${ }^{80}$

${ }^{77}$ Josep Puig Montada, “Reason and Reasoning,” 184-185.

${ }^{78}$ Ibidem.

${ }^{79}$ In modern European philosophy this view has been expressed many times, among others by Descartes.

${ }^{80}$ Rasa'il Ibn Hazm al-Andalusi, ed. Ihsan Abbas, 386-397. Ibn Hazm also writes about the intellect that it was given by God; he "refers to understanding or rational perception ('aqI) understood as a divine gift that transforms the human soul, giving it the certainty of being unchanging"; see: Vílchez, "Art and Aesthetics," 302. 
In addition to being similar to the ethics of the Stoics, the ethical views of the author of Al-Ahlāq wa-' l-Siyar also show a convergence with the philosophy of Aristotle. Ibn Hazm clearly repeats after Stagirite, writing in chapter IX, that "virtue [Arab. al-fadila] is something that is in between [Arab. al-wasita] - between exaggeration [Arab. al-ifrät] and deficiency [Arab. al-tafriț]. Each of these two extremes is to be condemned, while the virtue that lies between them is commendable [Arab. mahmūd]. The exception is the intellect [Arab. al-'aql] where there is no exaggeration." ${ }^{\prime 1}$

The convergence of the ethical views of Ibn Hazm on the one hand, and Aristotle and the Stoics on the other, are pointed out by contemporary Western researchers, including Montada, according to whom the Andalusian author simply tries to show that some of the views of (some) Greek philosophers are compatible with Islamic source texts. ${ }^{82}$ At the same time, modern scholars, when referring to these issues, agree that Ibn Hazm knew at least some Greek and Roman philosophers (e.g. Stoics), although rather second-hand, i.e. he did not read the original texts. $^{83}$

\section{Conclusion. Between ancient philosophy and the Quran}

In Al-Ahlāq wa-' 1-Siyar, Ibn Hazm focuses on two main issues: improving one's character, as well as the hardships and dangers of living between people (in society). He refers to these issues in his work as both a philosopher and a moralist. The Arab philosopher tries to determine what would be "soul medicine" and he is focusing on the world to come - which is something that the faithful should strive for. According to Ibn Hazm, such prioritization makes man internally (spiritually) calmer and able to better endure the hardships of life in this world.

At the same time, the author of Al-Ahlāq wa-' I-Siyar performs some kind of "demystification," writing what people really are, and not what they should be.

${ }^{81}$ Rasa'il Ibn Hazm al-Andalusi, ed. Ihsan Abbas, 399-400.

${ }^{82}$ Montada, Reason and Reasoning, 180.

${ }^{83}$ According to Mohammad Sharif Khan and Mohammad Anwar Saleem, for instance, Ibn Hazm "claimed to have read (evidently through translations) the works of the Milesian and Eleatic schools, of Euclid and Ptolemy, of Plato and Aristotle, and of Alexander of Aphrodisias." See Mohammad Sharif Khan, Mohammad Anwar Saleem, Muslim Philosophy and Philosophers (Dehli: APH Publishing, 1994), 38-44. 
In other words, instead of an idealized image of man, of human nature, of society, etc., he presents a real image - which, of course, raises much less optimism. Ibn Hazm strongly recommends not only not succumbing to illusions, but also - which no less important - relying on the indications of reason, and not only in matters of life, but also in religion.

However, in addition to being Islamic moralist, Ibn Hazm is also a philosopher. He clearly refers to some representatives of classical Greek philosophy, focusing - like many of them - on philosophy understood as "the art that teaches life." Just like the Stoics, he recommends a complete and consistent reliance on the intellect, and rejecting what is incompatible with reason. In addition to being influenced by Stoic philosophy, he is also clearly influenced by Aristotle's ethics, believing - like Stagirite - that all exaggeration in action leads to moral evil. The author of Al-Ahlāq wa-'I-Siyar also believes - like Socrates - that the acquisition of knowledge is a prerequisite for proper human development and progress in the field of morality. Apparently, the Arab author probably did not completely stick to the truth, stating that his philosophy, expressed in Al-Ahlāq wa-'I-Siyar, is (exclusively) the fruit of his own thoughts and life experience. Undoubtedly, he gained many valuable insights and reflections from the philosophers of ancient Greece and Rome. ${ }^{84}$

It is difficult to state unequivocally - taking into account the entire philosophy expressed in Al-Ahlāq wa-'I-Siyar - whether Ibn Hazm was more influenced by philosophical sources, or rather Islamic texts, since the postulates of not succumbing to whims (Stoic ethics), or the call to find moderation in own choices and actions (Aristotle), are also present in Islamic ethics based on the Quran and hadiths. ${ }^{85}$

\footnotetext{
${ }^{84}$ Somehow in the margins of these considerations, it is worthy to mention that philosophy expressed in the discussed treatise has the greatest formal convergence with Christian philosophy. On the other hand, one should not forget that Ibn Hazm was critical of Christianity, considering only Islam as the only religion deserving full recognition. These, above-mentioned formal similarities mainly relate to the belief that the ultimate sense and purpose of human life must be associated with God and the posthumous fate of the soul. In addition, Ibn Hazm would undoubtedly fully agree with the statement of - for example - Augustine that one should focus on knowledge about matters concerning God and own soul (i.e. religion, belief).

${ }^{85}$ For a general insight into the "classical" Islamic ethics derived from the Quran and hadiths, see, for example: George F. Hourani, Reason and Tradition in Islamic Ethics (Cambridge: Cambridge University Press, 2007), 23-48.
} 
In addition, the philosophy expressed in Al-Ahlāq wa-' I-Siyarcoincides with the views of other philosophers from the Arab-Muslim culture, especially with the representatives of so-called "classical" Arab philosophy (called falsafa). Just like the author of Al-Ahlāq wa-' l-Siyar, other Arab philosophers were very eager to use the solutions they found in ancient philosophy, while not departing from the basic indications of their religion. In the works of the first philosopher of this circle, Al-Kindī, we find a strong reliance (in his philosophical ethics) on Stoicism. ${ }^{86}$ The difference was that Ibn Hazm, unlike the most popular representatives of falsafa, was not very interested in such "classic" fields of philosophy as metaphysics or epistemology; unlike, for example, Al-Farābī, Avicenna or Averroes, he clearly focused on the philosophy understood as "wisdom of life." He was also able to find more advanced and interesting literary form, an example of which is $\mathrm{Al}$ Ahläq wa-'1-Siyar. Therefore, the originality of this treatise does not result from a double reference, both to ancient philosophy and Islam - because other ArabMuslim philosophers most often also participated in it - but rather from the author's reliance on his own life experience and attractive literary form, already mentioned.

It also seems that for this reason - but not only for this - Al-Ahlāq wa-' 1 Siyar is a work that can still be read today. Contemporary reader can easily find certain insights about, for example, friendship, appearances game between people, love or betrayal. In the area of human morality or interpersonal relations, little has probably changed since ancient times or the Middle Ages. And for this reason readers would still be interested in reaching for some "classic authors" of philosophical thought - such as, for instance, Seneca, Marcus Aurelius, Pascal or Schopenhauer - who focused mainly on "the art of life"; Andalusian philosopher, I believe, also should be considered to belong to this group.

\section{Bibliography}

Abu Layla, Muhammad. "An introduction to the life and work of Ibn Hazm." Islamic Quarterly 1985, no. 29: 165-171.

${ }^{86}$ For Al-Kindī's ethics, and especially for references (in his philosophy) to Greek philosophy, including the ethics of the Stoics, see: Peter Adamson, Al-Kindi. Great Medieval Thinkers (Oxford: Oxford University Press, 2007), 144-159. 
Adamson, Peter. Al-Kindi. Great Medieval Thinkers. Oxford: Oxford University Press, 2007. Chejne, Anwar G. "Ibn Hazm of Cordova on Logic." Journal of the American Oriental Society 104, no. 1 (1984), Studies in Islam and the Ancient Near East Dedicated to Franz Rosenthat: $57-72$.

Coope, Jessica A. "With Heart, Tongue, and Limbs: Ibn Hazm On the Essence of Faith." Medieval Encounters 6, issue 1-3 (2000): 101-113.

Danecki, Janusz. “W prowadzenie.” In Traktat o leczeniu dusz, kształceniu moralności i poskramianiu wad. Edited by Janusz Danecki. Warszawa: Wydawnictwo DIALOG, 1998.

Friedlaender, Israel. "The Heterodoxies of the Shiites in the Presentation of Ibn Hazm." Journal of the American Oriental Society 1908, no. 29: 1-183.

Giffen, Lois A. "Ibn Hazm and the Tawq al-Hamama." In The Legacy of Muslim Spain. Edited by Salma Khadra Jayyusi. Leiden: BRILL, 1992.

Guerrero, Rafael Ramón. “Aristotle and Ibn Hazm. On the Logic of the Taqrib.” In Ibn Hazm of Cordoba: The Life and Works of a Controversial Thinker. Edited by Camilla Adang, Maribel Fierro, 403-416. Leiden: BRILL, 2012.

Guthrie, William Keith Chambers. A History of Greek Philosophy, vol. 2: The Presocratic Tradition from Parmenides to Democritus. Cambridge: Cambridge University, 1965.

Hourani, George F. Reason and Tradition in Islamic Ethics. Cambridge: Cambridge University Press, 2007.

Ibn Hazm. Kitab al-Fịsal fi al-milal wa-al-ahwa wa-al-nịhal. N.p.: Ulan Press, 2012.

Ibn Ḥazm. Rasāì il Ibn Hazm al-Andalusī, vol. 1. Edited by Iḥsan Abbas. Beirut: Al-Mu'assasa al-'Arabiyya li-'l-dirasat wa-'1-nashr, 1987.

Khan, Mohammad Sharif, Mohammad Anwar Saleem. Muslim Philosophy and Philosophers. Dehli: APH Publishing, 1994.

Makki, Mahmoud. “The Political History of al-Andalus (92/711-897/1492).” In The Legacy of Muslim Spain. Edited by Salma Khadra Jayyusi, 3-87. Leiden: BRILL, 1992.

Martinez-Gros, Gabriel . "Ibn Hazm on History: A Few Remarks." In Ibn Hazm of Cordoba: The Life and Works of a Controversial Thinker. Edited by Camilla Adang, Maribel Fierro, 87-96. Leiden: BRILL, 2012.

Montada, Josep Puig. "Reason and Reasoning in Ibn Ḥazm of Cordova (d. 1064)”. Studia Islamica 2001, no. 92: 165-185.

Nykl, Alios Richard. "Ibn Hazm's Treatise on Ethics." The American Journal of Semitic Languages and Literatures 40, no. 1 (1923): 30-36.

Pellat, Charels. "Ibn Hazm al-Andalusi." Journal of the Pakistan Historical Society 9, no. 2 (1961): 71-74.

Puerta Vílchez, José Miguel. “Art and Aaesthetics in the Work of Ibn Hazm.” In Ibn Hazm of Cordoba: The Life and Works of a Controversial Thinker. Edited by Camilla Adang, Maribel Fierro, 253-373. Leiden: BRILL, 2012.

Puerta, Vílchez, José Miguel. “Abu Muhammad 'Ali Ibn Hazm: A Biographical Sketch.” In Ibn Hazm of Cordoba: The Life and Works of a Controversial Thinker. Edited by Camilla Adang, Maribel Fierro, 3-24. Leiden: BRILL, 2012. 
Puerta, Vílchez, José Miguel. "Inventory of Ibn Ḥazm's Works." In Ibn Hazm of Cordoba: The Life and Works of a Controversial Thinker. Edited by Camilla Adang, Maribel Fierro, 683-759. Leiden: BRILL, 2012.

Sabra, Adam . "Ibn Hazm's Literalism: A Critique of Islamic Legal Theory." In Ibn Hazm of Cordoba: The Life and Works of a Controversial Thinker. Edited by Camilla Adang, Maribel Fierro, 97-160. Leiden: BRILL, 2012.

Schmidtke, Sabine. "Ibn Hazm's Sources on Ash'arism and Mu'tazilism." In Ibn Hazm of Cordoba: The Life and Works of a Controversial Thinker. Edited by Camilla Adang, Maribel Fierro, 375-402. Leiden: BRILL, 2012.

Traktat o leczeniu dusz, kształceniu moralności i poskramianiu wad. Edited by Janusz Danecki. Warszawa: Wydawnictwo Akademickie DIALOG, 1998.

\section{Streszczenie}

\section{Ludzkie charaktery i moralność w filozoficznej aforystyce Ibn Ḥazma}

Celem artykułu jest analiza filozofii zaprezentowanej w traktacie $A l-A \underline{h} l \bar{a} q$ wa- 'l-Siyar Ibn Ḥazma. W pracy tej jej autor omawia między innymi takie kwestie jak przyjaźn, miłość, relacje między ludźmi w społeczeństwie, złożoność ludzkich charakterów czy różnorodność postaw życiowych; najważniejszą z podjętych tam kwestii jest jednak sens i znaczenie życia człowieka. Do wszystkich tych zagadnień, mimo prezentowania ostatecznie stanowiska wyraźnie religijnie zorientowanego, arabski filozof odnosi się jako racjonalista. Jego poglądy etyczne i moralistyka zakorzenione są nie tylko w tradycji religijnej (muzułmańskiej), lecz również w tradycji filozofii klasycznej, wykazując szczególnie silną zbieżność z etyką stoików i Arystotelesa.

Słowa kluczowe: filozofia, filozofia arabska, filozofia muzułmańska, etyka, moralistyka, aforystyka, islam, Ibn Ḥazm

\section{Zusammenfassung}

\section{Menschliche Charaktere und Moral in den philosophischen Aphorismen von Ibn Ḥazm}

Der Artikel setzt sich zum Ziel, die im Traktat Al-Ahlāq wa-'I-Siyar von Ibn Ḥazm dargestellte Philosophie zu untersuchen. Der Autor äußert sich in dieser Schrift über die Fragen der Freundschaft, Liebe, der zwischenmenschlichen Beziehungen in der Gesellschaft, über die 
Komplexität der menschlichen Charaktere und die Vielfalt der Lebenshaltungen. Jedoch die wichtigste der behandelten Fragen ist der Sinn und die Bedeutung des menschlichen Lebens. Der arabische Philosoph nimmt Stellung zu allen diesen Fragen als Rationalist, obwohl er letztendlich einen klar religiös orientierten Standpunkt repräsentiert. Seine ethischen Anschauungen und seine Moralistik sind nicht nur in der religiösen (muslimischen) Tradition verwurzelt, sondern auch in der Tradition der klassischen Philosophie, wobei sie besonders stark mit der Ethik der Stoiker und von Aristoteles übereinstimmen.

Schlüsselworte: Philosophie, arabische Philosophie, muslimische Philosophie, Ethik, Moralistik, Aphoristik, Islam, Ibn Ḥazm

Informacje o autorze:

TOMASZ STEFANIUK, doktor habilitowany, Instytut Filozofii, Uniwersytet Marii Curie-Skłodowskiej w Lublinie; adres do korespondencji: Instytut Filozofii UMCS, Pl. Marii Curie-Skłodowskiej 4, 20-031 Lublin; e-mail: tomasz.stefaniuk@poczta.umcs.lublin.pl 